\title{
O modelo didático no ensino do francês língua estrangeira: um estudo do gênero Itinéraire de Voyage
}

\section{The didatic model in teaching french as a foreign language: a study of the genre Itinéraire de Voyage}

\author{
Luiza Guimarães Santos ${ }^{1}$
}

\begin{abstract}
Resumo
Este trabalho tem por objetivo mostrar a relevância de se ensinar o francês como língua estrangeira, por meio dos gêneros textuais, especialmente, se assumimos que a perspectiva adotada é aquela que privilegia o agir em língua estrangeira. Ademais, almejamos refletir sobre a importância de se conhecer bem um gênero, antes de ensinar a produzi-lo e sobre as dificuldades envolvidas na elaboração do modelo didático de um gênero, particularmente, quando trabalhamos com línguas estrangeiras. Para tanto, relataremos nossa experiência, ao elaborar o modelo didático do gênero textual itinéraire de voyage, feito a partir da observação de diversos textos do mesmo gênero e conforme apresentado por Schneuwly e Dolz (2004). A fundamentação teórica deste estudo apoia-se nos trabalhos de Schneuwly e Dolz (2004) e Bronckart (1999, 2004, 2006), para a definição do conceito de gêneros textuais e para elaboração do modelo didático do gênero itinéraire de voyage. O modelo didático de um gênero consiste no levantamento das características de suas dimensões ensináveis e é uma das etapas para a adoção dos gêneros como objeto de ensino. Uma vez concluído, o modelo didático pode ser usado como instrumento, para que o professor escolha o que irá ensinar e como.

Palavras-chave: Gêneros textuais. Modelo didático. Ensino de francês. Gênero itinéraire de voyage.
\end{abstract}

\begin{abstract}
This paper aims to show the relevance of teaching French as a foreign language through text genres, especially if we assume that the perspective adopted is one that privileges the action in a foreign language. In addition, we aim to reflect about the importance of knowing a genre before teaching how to produce it as well as point some difficulties involved in the elaboration of a didactic model, particularly when working with foreign languages. Therefore, we will analyze the genre itinéraire de voyage, and from observation of several texts of the same genre, we will elaborate a didactic model of this genre, as presented by Schneuwly and Dolz (2004). The theoretical basis of this study relies on the work of Schneuwly and Dolz (2004) and Bronckart $(1999,2004,2006)$ for the definition of textual genres and the elaboration of a didactic model of the genre itinéraire de voyage. The didactic model of a genre is a collection of the characteristics of its teachable dimensions and is one of the steps towards the adoption of genres as a teaching object. Once completed, the didactic model can be used as a teaching tool for the teacher to choose what he/she will teach and how.
\end{abstract}

Keywords: Text genres. Didactic model. Genre itinéraire de voyage. Teaching of French.

${ }^{1}$ Mestre em Letras, Língua e Literatura Francesa pela Universidade de São Paulo e integrante do grupo de pesquisa ALTER-AGE (Análise de Linguagem, Trabalho e suas Relações - Aprendizagem, Gêneros textuais e Ensino).Email: luiza.gs@gmail.com 


\section{Introdução}

A questão dos gêneros textuais vem sendo cada vez mais estudada na última década no Brasil, nos contextos de língua materna, como atestam os Parâmetros curriculares nacionais (PCN) (BRASIL, 1998). No entanto, nos contextos de língua estrangeira, a questão dos gêneros textuais tem apenas recentemente ocupado certo espaço e ainda não despertou o mesmo interesse que já existe em relação à língua materna. Nesse sentido, faz-se necessária uma discussão sobre as inúmeras questões decorrentes da transposição didática dos conceitos teóricos sobre gêneros textuais e sobre a análise de textos (LOUSADA, 2008).

O presente estudo baseou-se nos pressupostos teóricos do interacionismo sociodiscursivo (ISD), apresentado por Bronckart (1999, 2004, 2006, 2008), sobretudo no que diz respeito à questão dos gêneros textuais e ao modelo de análise de textos. Usamos o conceito de atividade social proposto por Bronckart (2004) que explica que agimos no mundo por meio de atividades sociais: linguageiras e não linguageiras. Também nos baseamos nos trabalhos de Schneuwly e Dolz (2004), que exploram o uso de gêneros textuais para o ensino de língua materna (francês) na Suíça francófona, e explicam a elaboração do modelo didático de um gênero textual. Além disso, adotamos a noção de gênero textual não apenas como unidade de ensino, mas como ferramenta que atua no processo de aprendizagem. Nesse sentido, o gênero é considerado um verdadeiro instrumento para o desenvolvimento de três tipos de "capacidades de linguagem". Essas capacidades representam três níveis fundamentais de operações de linguagem em funcionamento: representação do contexto social ou contextualização (capacidades de ação); estruturação discursiva do texto (capacidades discursivas); escolha de unidades linguísticas ou textualização (capacidades linguístico-discursivas) (SCHNEUWLY; DOLZ, 2004).
Neste artigo, nosso objetivo específico é apresentar o modelo didático do gênero textual itinéraire de voyage, baseado na análise de textos autênticos. Após essa análise, explicitaremos alguns benefícios que a noção de gêneros textuais e a elaboração de um modelo didático podem aportar para o ensino de línguas, salientando a importância de se conhecer bem um gênero antes de ensinar a produzi-lo. Finalmente, apresentaremos algumas dificuldades que enfrentamos, ao elaborar o modelo didático do gênero itinéraire de voyage.

Para a elaboração do modelo didático do gênero itinéraire de voyage, coletamos vários textos pertencentes a esse gênero e, a partir dessa coletânea, analisamos os textos no que diz respeito ao contexto de produção e ao folhado textual ${ }^{2}$. O modelo didático tem o objetivo de guiar as práticas de ensino do gênero, sendo uma das etapas da transposição didática que leva à construção da sequência didática. A elaboração de um modelo didático aponta o conhecimento implícito do gênero e evidencia as suas dimensões ensináveis, orientando as intervenções dos professores (SCHNEUWLY; DOLZ, 2004).

A justificativa da seleção do gênero itinéraire de voyage está fundamentada nos conceitos de domínios e de agir social do Quadro Europeu Comum de Referência (CONSEIL DE L'EUROPE, 2001) e também nas propostas de dimensões de Cristovão (2002). Conforme explicitado pelo Quadro Comum de Referência, a língua permite aos seus aprendizes agir socialmente, e viajar é uma forma de agir social, sendo que antes de viajar costuma-se fazer uma preparação através de alguns textos. Em outras palavras, estamos trabalhando com o agir social viajar e com os gêneros que fornecem informações sobre esse agir e que auxiliam, sobretudo, na preparação da viagem.

Sendo assim, apresentaremos inicialmente os pressupostos teóricos que permeiam o conceito de gêneros textuais e de modelo didático. Em

\footnotetext{
${ }^{2}$ Baseado no modelo de análise textual do interacionismo sociodiscursivo, que será explicado em detalhes mais adiante.
} 
seguida, detalharemos o modelo de análise textual desenvolvido pelo ISD e exemplificaremos esse modelo a partir da análise de textos autênticos pertencentes ao gênero itinéraire de voyage. Encerraremos nosso artigo, apresentando algumas reflexões sobre a importância do modelo didático para o ensino de línguas estrangeiras, assim como algumas dificuldades para realizá-lo.

\section{Os Gêneros Textuais}

Este artigo está embasado no interacionismo sociodiscursivo, desde os pressupostos teóricos até os procedimentos metodológicos de análise dos dados, que serão explicados mais adiante. Neste trabalho, focaremos no nível dos pré-construídos e apresentaremos o modelo de arquitetura interna dos textos. O ISD apoia-se no conceito de gênero do discurso desenvolvido por Bakhtin, afirmando que a ação de linguagem é realizada pelo uso dos gêneros disponíveis em uma dada formação social. Bakhtin (1997, p. 279) define os gêneros do discurso como sendo "tipos relativamente estáveis de enunciados, presentes em cada esfera da atividade humana e sócio-historicamente construídos". Os gêneros discursivos têm, segundo Bakhtin (1997), três características básicas: tema, organização composicional e estilo. Dentro do quadro teórico do ISD, Bronckart (1999) propõe o termo gênero textual, afirmando que são os textos que se organizam em gêneros, ficando a terminologia de tipos de discurso para uma outra categoria que engloba os diferentes "mundos discursivos" que o produtor do texto pode criar. Nesse sentido, os gêneros textuais são construtos históricos, os quais se modificam na medida em que as questões sociocomunicativas evoluem, ou seja, para o ISD, os gêneros textuais não são formas fixas (BRONCKART, 1999).

$\mathrm{O}$ agir linguageiro designa a realidade linguageira constituída de práticas de linguagem situadas e realiza-se por meio de textos. Segundo Bronckart (2006), o texto corresponderia a uma unidade comunicativa ou interativa global e poderia ser definido como uma unidade de agir linguageiro que veicula uma mensagem organizada e que tende a produzir um efeito de coerência sobre o destinatário, em um determinado espaço e num determinado tempo. Dessa forma, como existem diferentes formas de agir linguageiro, ou de textos, o autor propõe o uso de "gêneros de textos" e não de gêneros do discurso, considerando que as expressões são equivalentes. Todo texto pertence a um gênero, apresentando propriedades genéricas, resultantes da escolha do gênero textual, mas tem especificidades sempre únicas, que derivam das escolhas do produtor em função de sua situação de produção particular.

Do ponto de vista da didática da produção textual, por meio de gêneros, o trabalho com gêneros textuais atua na aprendizagem da língua e no desenvolvimento das capacidades de linguagem do aluno (LOUSADA, 2010). Schneuwly e Dolz (2004) explicam que uma das funções do gênero é possibilitar o desenvolvimento das diferentes capacidades de linguagem que mobilizamos na leitura e na produção de um texto. Assim, ao ensinar um gênero, na verdade, estamos auxiliando o desenvolvimento dessas capacidades de linguagem. Os autores Schneuwly e Dolz (2004) explicam que três capacidades englobam as capacidades de linguagem, a saber: capacidade de ação, capacidades discursivas e capacidades linguísticodiscursivas, sendo que a primeira representa a aptidão de adaptar-se às características do contexto e do referente, a segunda envolve a mobilização de modelos discursivos e a terceira equivale ao domínio das operações psicolinguísticas e as unidades linguísticas.

O texto, enquanto pertencente a um gênero, deve tornar-se a unidade básica de uma aula de língua e o ensino precisa levar o aluno a dominar as situações de comunicação e, portanto, os gêneros necessários para esta. Os gêneros estão em constante movimento, extinguindo-se ou se alterando, para permitir o surgimento de novos gêneros ou, então, 
para se adaptar às novas necessidades sociais. Cada campo de utilização da língua (literatura, ciência, escola, medicina, lazer etc.) cria tipos relativamente estáveis de enunciados, isto é, gêneros textuais (contos, poemas, teses, relatórios, provas, bulas, atestado médico, conversa, bilhete, e-mail etc.), que se caracterizam pelos seus conteúdos e pelos meios linguísticos de que se utilizam. Sendo os gêneros artefatos linguístico-culturais concretos (MARCUSCHI, 2002), o trabalho com eles é uma boa oportunidade de se lidar com a língua, em seus mais diversos e autênticos usos no dia a dia, mostrando-a para o aluno como algo vivo, que está em constante movimento.

\section{A Noção de Modelo Didático}

A arquitetura de qualquer texto é complexa, portanto, é necessário elaborar um modelo didático do gênero escolhido como objeto de ensino. Esse modelo reúne os conhecimentos teóricos disponíveis sobre esse gênero, seleciona-os e os transpõe, isto é, adapta-os às propriedades do sistema didático envolvido (BRONCKART, 2010). O modelo didático de um gênero consiste no levantamento das características de suas dimensões ensináveis que, segundo Bronckart (1999, 2006), são a situação de produção, os aspectos discursivos e os aspectos linguístico-discursivos. O modelo didático está estreitamente ligado às capacidades de linguagem necessárias à produção de textos.

Ao elaborar um modelo didático, é preciso ter em mente três princípios: o da legitimidade, referente ao saberes elaborados por especialistas; o da pertinência, concernente às capacidades dos alunos, às finalidades da escola e aos processos de ensino-aprendizagem; e o da solidarização, alusivo à ideia de que os saberes devem ser coerentes, em função dos objetivos visados. Um modelo didático é elaborado com alguns objetivos, entre eles, pensar a progressão temporal do ensino, conceber possibilidades de diferenciação e planificar o ensino propriamente dito, elaborando sequências didáticas. A partir de um modelo didático, diversas sequências didáticas podem ser propostas. Além disso, cada uma das dimensões ensináveis pode representar uma progressão a ser trabalhada, iniciando-se, por exemplo, com uma simples sensibilização e culminando em uma produção (SCHNEUWLY; DOLZ, 2004).

Quanto mais precisa for a definição das dimensões ensináveis de um gênero, mais ela facilitará a apropriação deste como instrumento e mais ela possibilitará o desenvolvimento de capacidades de linguagem relacionadas a esse gênero (MACHADO; CRISTOVÃO, 2006). É importante ressaltar que o modelo didático não precisa ser teoricamente puro, como apontam os autores Schneuwly e Dolz (2004), já que tem a função maior de apontar as dimensões ensináveis desse gênero e não de esgotar suas análises possíveis. É importante lembrar, ainda, que, para a realização do modelo didático de um gênero, é necessário analisar vários textos do mesmo gênero, antes de poder considerar que as características presentes em um texto são as características predominantes de um determinado gênero. Sendo assim, é importante que o modelo didático procure representar as características comuns à maioria dos textos pertencentes àquele gênero (LOUSADA, 2010).

A seguir, explanaremos o modelo de arquitetura interna dos textos proposto por Bronckart (1999, 2006) e que será utilizado em nosso artigo para analisar os textos autênticos e criar o modelo didático do gênero itinéraire de voyage.

\section{Modelo de Análise de Textos do ISD}

O modelo sugerido por Bronckart é composto pela infraestrutura global do texto, dividida em plano geral/global do texto, tipos de discurso e sequências; pelos mecanismos de textualização, constituídos pela conexão, coesão nominal e coesão verbal; e pelos mecanismos de responsabilização enunciativa, 
divididos em modalizações e vozes. Além dessa estrutura, o próprio autor destaca a necessidade de compreensão do contexto de produção do texto, antes de qualquer análise textual (BRONCKART, 1999).

Portanto, o estudo inicia-se no contexto de produção do texto, que deve ser analisado desde o contexto mais amplo, sócio-histórico, ao contexto mais imediato, da ação de linguagem. O contexto imediato em que o texto foi produzido contempla a situação que deu origem ao texto (BRONCKART, 1999, 2006). Para esta análise, levantamos hipóteses sobre: quem escreveu o texto, para quem o escreveu, em qual momento, com qual objetivo etc. Observamos o contexto físico que deu origem ao texto, mas focamos nossa atenção no contexto sociossubjetivo, ou seja, o lugar social onde o texto foi produzido, o papel social desempenhado pelo produtor e pelo receptor e que efeitos o enunciador queria produzir no destinatário.

Após compreender bem o contexto de produção, o folhado textual será analisado sob a ótica da infraestrutura geral do texto, composta pelo plano global dos conteúdos temáticos, pelos tipos de discurso e pelas sequências. O plano global dos conteúdos temáticos corresponde aos conteúdos que aparecem no texto, como se fosse um resumo do texto. Já os tipos de discurso correspondem a mundos discursivos construídos na produção textual. Os tipos de discurso podem ser entendidos como pertencentes a dois eixos principais: narrar e expor. O eixo do narrar (disjunção) pode ser implicado ou autônomo, ou seja, pode apresentar ou não implicação em relação ao ato de produção (através de dêiticos espaciais, temporais e de pessoa). O eixo do expor (conjunção) pode também ser implicado ou autônomo. Sendo assim, dentro desses dois eixos, há uma outra divisão que dá origem aos tipos de discurso: narrar - disjunto e autônomo (tipo de discurso narração); narrar - disjunto e implicado (tipo de discurso relato interativo) e expor conjunto e implicado (tipo de discurso interativo) e expor - conjunto e autônomo (tipo de discurso teórico) (BRONCKART, 1999).
Ainda no nível da infraestrutura textual, temos as sequências, que aparecem geralmente combinadas e dividem-se em: narrativa, descritiva, argumentativa, explicativa, injuntiva e dialogal. Além disso, Bronckart (1999, 2006) apresenta o grau zero da sequência narrativa, na qual não há intriga, tensão, que seria o script e o grau zero das sequências argumentativa e explicativa, a esquematização, mobilizada quando não há a necessidade de explicar algo de difícil compreensão ou argumentar em favor ou contra algo que pode ser contestável.

Seguindo agora para o segundo nível de análise do folhado textual, surgem dois tipos de mecanismos que contribuem para dar aos textos uma coerência global: os mecanismos de textualização, que exploram os recursos linguísticos para assegurar a progressão temática e os mecanismos enunciativos: mais ligados à organização geral do gênero e que tornam explícitos os jogos de vozes e os julgamentos dos quais emana o conteúdo temático de um texto. Os mecanismos de textualização compreendem a coerência e a coesão. A primeira diz respeito às relações entre os níveis de organização de um texto e é explicitada pelos organizadores textuais. A segunda pode ser dividida em coesão nominal (retomadas nominais e pronominais; anáforas e catáforas) e verbal (tempos e modos verbais) (BRONCKART, 1999).

No terceiro nível do folhado textual, encontramos os mecanismos enunciativos que dão a clarificação dialógica do texto das modalizações e que são responsáveis pelas diversas avaliações do enunciador sobre um ou outro aspecto do conteúdo temático. As modalizações podem ser divididas, segundo Bronckart (1999), em lógicas, deônticas, pragmáticas e apreciativas. Estas últimas envolvem as apreciações subjetivas do enunciador, que avaliam o conteúdo temático do enunciado como sendo negativo, positivo etc. para o enunciador. Já as vozes explicitam as instâncias que assumem ou se responsabilizam pelo que está sendo dito e, também, fazem parte dos mecanismos enunciativos. 
Maingueneau (2001) sustenta que o processo de inserção de vozes pode acontecer por meio de vários recursos, tais como: discurso direto, direto livre, indireto, indireto livre, ilhas enunciativas, aspas, entre outros.

A partir dos procedimentos metodológicos de análise que acabamos de mostrar, realizamos a análise de textos autênticos do gênero itinéraire de voyage e criamos o seu modelo didático, apresentados a seguir.

\section{Modelo Didático do Gênero Itinéraire de Voyage}

Selecionamos dez textos autênticos, para análise e elaboração do modelo didático do gênero itinéraire de voyage. Os textos foram encontrados nas seções Activités et Excursions (revista Nouvelles Frontières Hôtels Clubs); Itinéraire Indicatif (revista Nouvelles Frontières L'aventurer); Circuit Découverte (revista Marmara); Combiné (revista Marmara); Idées Week-end (site do Routard); Reportages (site do Routard); Guide de Voyage - Conseils (site GEO); Guide de Voyage Monuments (site L'internaute); Guide de Voyage - Itinéraire (site L'internaute); Circuits Michelin (site ViaMichelin). Para poder selecionar os textos autênticos que seriam utilizados para a elaboração do modelo didático, nosso principal critério foi que o texto deveria apresentar sugestões de atividades na cidade ou no país em questão. Isso se justifica porque nosso objetivo era trabalhar com o agir social "viajar", focando a preparação prévia. Apesar de ser também anterior à viagem, não nos interessava trabalhar, naquele momento, com aspectos mais práticos, como reservas de hotéis, necessidade de vistos, transportes etc. Queríamos que os alunos conseguissem, por meio dos textos, conhecer as principais atrações turísticas e os principais passeios que podem ser realizados em determinada cidade ou país. Desse modo, eles saberiam o que podem fazer e/ou visitar, quando viajarem para aquele local. Apenas um texto de cada seção foi utilizado e as cidades, regiões ou países tema dos textos autênticos foram escolhidos aleatoriamente. Outros lugares poderiam ter sido escolhidos, sem que a análise dos textos fosse prejudicada. E, na próxima seção, apresentaremos os resultados das análises desses textos.

O contexto de produção é o nosso primeiro plano de análise para elaboração do modelo didático. Sabemos que o contexto físico de produção envolve um emissor, um receptor, um local de produção e um momento de produção. Paralelamente, o contexto social de produção envolve um enunciador, um destinatário, um lugar social e um (ou mais) objetivo(s) da interação. Com relação ao emissor, nenhum dos textos do itinéraire de voyage é assinado, portanto, não sabemos quem os escreveu. Porém, podemos levantar hipóteses sobre o seu papel social. O enunciador dos textos é alguém com vasto conhecimento sobre a cidade ou o país sobre o qual ele escreve. Pode ser, por exemplo, um repórter especializado ou um viajante que conheça o local. Talvez seja um funcionário das empresas que publicaram o texto ou, então, alguém contratado por essas empresas, especialmente, para escrever esse texto. Existe, portanto, um macro enunciador, que são as revistas e os sites nos quais o texto se insere. Em outras palavras, o repórter ou funcionário não fala por si, ele fala em nome dessa revista/site. O receptor também não é conhecido. No plano social, o destinatário é alguém com interesse em viajar ou em aprofundar seus conhecimentos sobre um determinado local. Ele pode ser alguém com uma viagem já agendada, que precisa escolher que locais irá visitar enquanto estiver viajando. Ou pode ser também alguém que pretende viajar, mas ainda não sabe para onde e se baseia nos textos para escolher seu destino. Emissor e receptor não se encontram no contexto físico: o leitor desconhece quem é o autor do texto e o escritor não sabe quem são as pessoas que lerão seu texto.

Ao utilizar as brochuras das agências, a pessoa busca um pacote de viagem, com hotel, transporte 
aéreo, traslados etc. Por outro lado, as pessoas que acessam os outros sites, provavelmente, organizarão sua viagem por conta própria, escolhendo um hotel, uma companhia aérea, o numero de dias em cada cidade etc. Na primeira opção, existe uma menor flexibilidade de escolha, pois os pacotes são previamente montados e o turista deve escolher entre as opções apresentadas. Ao mesmo tempo, existe uma maior segurança, pois a viagem será organizada com o suporte de uma agência renomada e a orientação de pessoas treinadas. Existe, também, uma maior comodidade, pois o viajante não precisa pesquisar vários itens separadamente, basta escolher a opção que mais lhe agrada e tudo será fechado diretamente com a agência. Além disso, algumas pessoas não se sentem confortáveis de pesquisar ou comprar na Internet. No caso da revista da agência, a pessoa pode ter acesso às informações de que precisa em um material físico e ainda pode ter contato direto com os funcionários da agência, sem a necessidade de fechar negócio com uma máquina.

O objetivo das revistas de agências de turismo, ao mostrar aos destinatários quais são as atrações de cada destino, é vender um de seus pacotes turísticos. Não é a informação pela informação, mas a informação pela venda. Ou seja, o centro das revistas acaba não sendo os destinos em si. Os lugares são apenas um meio de fazer propaganda sobre os pacotes da agência. Em outras palavras, a agência não está interessada em falar das belezas de determinado lugar apenas para que o destinatário saiba disso, mas para que o destinatário se interesse tanto em conhecer esse local a ponto de fechar um pacote com a agência. É por isso que as revistas possuem um tom "marqueteiro". Destinatários que desejem aprofundar seus conhecimentos sobre um determinado local, dificilmente, utilizarão essas revistas, dado que as explicações são curtas e muito espaço é utilizado para descrever os hotéis do grupo, os preços etc. As revistas são uma maneira de auxiliar as pessoas a escolherem sua próxima viagem, apresentando as vantagens individuais de cada destino e de cada pacote oferecido. A revista é bastante autoexplicativa e reduz o tempo que as pessoas precisam passar na agência. Alguém vai até a agência retirar a revista, pode lê-la, quando e onde achar mais conveniente, e depois voltará para a agência já para fechar negócio, otimizando o tempo do viajante e dos funcionários.

Por outro lado, acreditamos que o principal objetivo dos textos da Internet é retratar características, dados, curiosidades e informações gerais sobre as cidades e países abordados, estimulando o leitor a conhecer essa região. Ademais, o texto serve também para que o destinatário tenha posse de algumas informações sobre o seu destino e não fique sem saber para onde ir ou o que fazer quando estiver viajando. Como uma finalidade secundária, os sites objetivam vender pacotes turísticos e/ou guias e revistas de viagem impressos. No caso das revistas de agências, a venda constitui o principal objetivo, enquanto que os objetivos primordiais dos sites, apesar de estarem também presentes, são secundários. Todos os textos que estamos analisando estavam publicados em 2011. Em relação aos textos das brochuras, acreditamos que tenham sido produzidos em 2010 ou 2011 e, provavelmente, foram escritos especialmente para as publicações às quais pertencem. Já os textos da Internet não possuem data e não é possível saber efetivamente quando eles foram produzidos.

Quando iniciamos a análise do folhado textual, observamos que a maioria dos textos possui um titulo, geralmente, com o nome da seção à qual pertence e divide-se em parágrafos. Todos os textos, inclusive os das brochuras, iniciam-se com um parágrafo introdutório sobre a cidade, pais ou região. Esse parágrafo contém frases bastante positivas sobre o local para que o leitor sinta-se estimulado a visitá-lo. Nos parágrafos seguintes, ocorre uma descrição mais detalhada sobre o destino e seus principais pontos turísticos. Nos documentos das revistas de agências de turismo, cada parágrafo representa as atividades de um dia da viagem e a descrição contempla, também, os deslocamentos a serem feitos pelo viajante. Os documentos são ricos em fotos dos locais descritos. 
Com relação às sequências, predominam as descritivas, justamente pelo que acabamos de expor: o texto preocupa-se essencialmente em descrever o local, os passeios, as atividades etc. Há também a presença de sequências argumentativas, pois um dos objetivos do texto é convencer o leitor a viajar para o destino que está sendo descrito. Quanto ao discurso presente nos textos, há uma prevalência do discurso teórico, também, conhecido como expor autônomo, que possui ausência de marcas de referência aos participantes da interação, presença do sujeito genérico e predomínio de frases declarativas. No entanto, encontramos, também, a presença do discurso interativo, que é quando o enunciador interage com o receptor ("Commencez donc votre visite", “Vous y découvrirez”). Ou seja, ele adota uma atitude de locução no gênero. A presença do discurso interativo pode cumprir dois papéis fundamentais neste gênero: i) aproximar o leitor do enunciador, aumentando a confiança do primeiro no segundo e, consequentemente, ampliando a margem de convencimento do enunciador; ii) transmitir ao destinatário uma ideia de projeto, ou seja, de algo que ele realizará no futuro. Dessa forma, o local não faria parte apenas da descrição do enunciador, mas também dos projetos futuros do leitor, que, em breve, estaria realizando, pessoalmente, as atividades e os passeios no local em questão. $\mathrm{O}$ discurso interativo está presente de forma ainda mais intensa nas revistas de agências, pois, ao cumprir os dois papeis explicitados acima, o texto estimula, de forma implícita, a venda dos pacotes de viagem por meio do discurso.

Ainda no segundo nível de análise do folhado textual, temos os mecanismos de textualização, que envolvem a coesão verbal, coesão nominal e a coerência. Com relação à coerência, não encontramos muitos elementos conectivos comumente usados. No caso das revistas de agências, os conectivos de enumeração são mais frequentes ("ensuite", "après", "durant", "enfin”). Eles servem para indicar as etapas dos passeios e das excursões que serão realizadas pelos viajantes. A maioria das frases é curta e existe um predomínio de frases declarativas. A conexão é dada, principalmente, por justaposição de conteúdos temáticos organizados de forma cronológica, sem marcas de conectivos comumente usados para a transição entre tipos de discurso e entre fases de uma sequência.

Quanto à coesão verbal, percebemos diferenças entre os textos dos sites e os das revistas de agências. Nos documentos extraídos da Internet, os verbos estão, geralmente, no presente, utilizados para falar sobre as características da região, como ela é. Algumas frases são escritas no passado para contar algo histórico sobre a cidade ou país. Há, também, com certa frequência, o uso do imperativo ( " $n$ 'hésitez pas", "faites", "n'oubliez pas de saluer"), para indicar o que turista deve fazer ou aonde ele deve ir. Em alguns textos, encontramos verbos no futuro ("vous y découvrirez", "permettra", "vous goûterez"), mas eles não são tão frequentes. Já no caso das revistas de agência, o futuro aparece de forma intensa nos textos ("un guide répondra", "vous aurez", "vous partagerez", "nous nous dirigerons"). $\mathrm{O}$ uso desse tempo verbal corrobora com a ideia de projeto, apresentada na seção anterior, e é especialmente importante para as agências de turismo. De forma bem mais restrita, encontramos alguns textos que apresentam a nominalização de alguns verbos ("après le déjeuner, découverte de Tunis", "la visite", "la reserve”, "retour"). Em todos os textos, ocorre forte presença também de particípios ("présentés”, "organisée”, "préparé”, "consacrée", "située”, "bordée”, "réservés", “installée”).

Quanto à coesão nominal, encontramos uma alta densidade nominal, com forte presença de anáfora para evitar a repetição. Como, por exemplo, no caso do nome da cidade, que é substituída pelos substantivos "la capitale", "la ville" e pelo pronome " $y$ ".

Com relação aos mecanismos enunciativos, encontramos com bastante frequência modalizações apreciativas, a julgar pelas palavras escolhidas 
para caracterizar os lugares descritos ("grande réputation", "lieu incontournable”, "une vraie image de carte postale", "destination week-end privilégiée”), inclusive o uso dos verbos amar, admirar (aimerez, admirerez). Ainda com relação aos mecanismos enunciativos, encontramos somente a voz do enunciador. Os enunciadores assumem papéis diferentes, segundo os locais em que estão escrevendo e segundo seus destinatários. Parece que o enunciador se adapta a esse destinatário, pois quer produzir um efeito de persuasão, de convencimento. Nesse sentido, o enunciador falará para um turista ávido de aventuras e exotismo, em algumas viagens; para um turista que quer história, em outras viagens e assim sucessivamente. Para isso, o enunciador deixa entrever, nos casos analisados, a voz do europeu, que considera determinadas coisas como exóticas, como relevantes etc. Enfim, o enunciador deixa entrever outras vozes, dependendo do contexto. Todos os conteúdos temáticos mobilizados e todas as modalizações escolhidas dependem dessa posição enunciativa.

Podemos resumir as informações levantadas sobre o modelo didático do gênero itinéraire de voyage no quadro abaixo, elaborado de acordo com os procedimentos explicados no item 3 deste artigo.

Quadro 1 - O modelo didático do gênero itinéraire de voyage

\begin{tabular}{|c|c|}
\hline & Contexto De Produção \\
\hline $\begin{array}{l}\text { Enunciador } \\
\text { (Quem escreveu?) }\end{array}$ & $\begin{array}{l}\text { Repórteres especializados ou viajantes que conhecem profundamente o destino sobre o qual se } \\
\text { está falando. A maioria dos textos não é assinada. Existe um macro enunciador que é a revista, } \\
\text { a agência ou o site. Essas empresas tentam criar uma persona (por exemplo, o Roudard é o } \\
\text { mochileiro aventureiro). Essa persona influenciará as escolhas dos conteúdos temáticos. }\end{array}$ \\
\hline $\begin{array}{l}\text { Destinatário } \\
\text { (Para quem?) }\end{array}$ & $\begin{array}{l}\text { Para qualquer pessoa que queira viajar ou queira conhecer mais sobre um determinado país ou } \\
\text { uma determinada cidade. Pode ser alguém com uma viagem já agendada ou pode ser também } \\
\text { alguém que pretende viajar, mas ainda não sabe para onde e se baseia nos textos para escolher } \\
\text { seu destino. Assim como cada empresa possui uma persona, cada uma delas também visa a um } \\
\text { destinatário mais específico (exemplos: a revista Nouvelles Frontières L'aventure e o Roudard } \\
\text { falam para uma pessoa aventureira, enquanto que as revistas Nouvelles Frontières Hôtels Club e } \\
\text { Marmara possuem como destinatário principalmente as famílias). }\end{array}$ \\
\hline \multirow{3}{*}{ Lugar social } & $\begin{array}{l}\text { A) Brochuras e sites de agências de viagem. } \\
\text { Os textos analisados foram produzidos nas seções: Activités et Excursions (revista Nouvelles } \\
\text { Frontières Hôtels Clubs); Itinéraire Indicatif (revista Nouvelles Frontières L'aventure); Circuit } \\
\text { Découverte (revista Marmara); Combiné (revista Marmara); }\end{array}$ \\
\hline & $\begin{array}{l}\text { B) Sites da Internet sobre viagem. } \\
\text { Os textos analisados foram produzidos nas seções: Idées Week-end (site do Routard); Reportages } \\
\text { (site do Routard); Guide de Voyage-Monuments (site L'internaute); Guide de Voyage-Itinéraire } \\
\text { (site L'internaute); }\end{array}$ \\
\hline & $\begin{array}{l}\text { C) Revistas de viagem. } \\
\text { Os textos analisados foram produzidos na seção itinéraires da revista Détours en France. }\end{array}$ \\
\hline
\end{tabular}




\begin{tabular}{|c|c|}
\hline \multirow[t]{3}{*}{$\begin{array}{l}\text { Objetivo } \\
\text { (Por quê?) }\end{array}$} & $\begin{array}{l}\text { Para que o destinatário tenha posse de algumas informações sobre o seu destino e não fique } \\
\text { sem saber para onde ir ou o que fazer quando estiver viajando. Além disso, serve também para } \\
\text { retratar características, curiosidades e informações gerais sobre as cidades e países abordados, } \\
\text { apresentando as regiões de maneira detalhada, completa, interessante e atrativa para que o leitor } \\
\text { faça sua escolha . Ênfase em atividades/lazer e não em informações gerais, justamente porque } \\
\text { o texto sugere ao leitor o que fazer enquanto estiver viajando. Apesar desse objetivo comum, é } \\
\text { preciso destacar que: }\end{array}$ \\
\hline & $\begin{array}{l}\text { A) O objetivo das brochuras e dos sites de agências de viagem, ao mostrar aos destinatários quais } \\
\text { são as atrações de cada destino, é vender um de seus pacotes turísticos. Ou seja, os lugares são } \\
\text { apenas um meio de fazer propaganda sobre os pacotes da agência. }\end{array}$ \\
\hline & B) e C) Já o principal objetivo dos sites de viagem e das revistas de viagem é fidelizar o leitor. \\
\hline Quando? & $\begin{array}{l}\text { As brochuras de agências e as revistas de viagem foram publicadas em } 2011 \text {. A maioria dos textos } \\
\text { dos sites de viagem não possui data, mas todos estavam disponíveis no momento em que este } \\
\text { trabalho foi realizado. Os textos são escritos para que sejam lidos antes de o leitor realizar uma } \\
\text { viagem ou enquanto ele realiza uma. }\end{array}$ \\
\hline \multicolumn{2}{|r|}{ INFRAESTRUTURA GERAL } \\
\hline \multirow[t]{4}{*}{$\begin{array}{l}\text { Plano } \\
\text { global } \\
\text { dos } \\
\text { conteúdos } \\
\text { temáticos e } \\
\text { Layout }\end{array}$} & $\begin{array}{l}\text { Título; texto introdutório; parágrafos; imagens. } \\
\text { A maioria dos textos inicia-se com um parágrafo introdutório sobre a cidade, país ou região. Esse } \\
\text { parágrafo contém frases bastante positivas sobre o local, para que o leitor sinta-se estimulado a } \\
\text { visitá-lo. Nos parágrafos seguintes, ocorre uma descrição mais detalhada sobre o destino e seus } \\
\text { principais pontos turísticos. Não há um plano idêntico em todos os textos. }\end{array}$ \\
\hline & $\begin{array}{l}\text { A) No caso das brochuras de agências, cada parágrafo representa as atividades de um dia da } \\
\text { viagem ou cada parágrafo representa um passeio turístico diferente. Os textos apresentam o preço } \\
\text { e as vantagens daquele pacote. }\end{array}$ \\
\hline & $\begin{array}{l}\text { B) Nos sites de viagem, os textos são, geralmente, contínuos e os parágrafos não necessariamente } \\
\text { falam de um único passeio. Presença de hipertextos. }\end{array}$ \\
\hline & $\begin{array}{l}\text { C) Nas revistas de viagem, aparece geralmente primeiro o texto introdutório, seguido do título e } \\
\text { depois vem o texto principal, que é dividido em duas colunas. }\end{array}$ \\
\hline $\begin{array}{l}\text { Tipos de } \\
\text { Discurso }\end{array}$ & $\begin{array}{l}\text { Discurso teórico (expor autônomo); Discurso interativo (expor implicado): o enunciador interage } \\
\text { com o receptor ("Commencez donc votre visite”, “Vous y découvrirez") para aproximar o leitor } \\
\text { do enunciador e para dar a ideia de projeto. Apesar de o enunciador interagir com o destinatário, } \\
\text { ele não fala em primeira pessoa e não identifica o local em que se encontra. }\end{array}$ \\
\hline Sequências & $\begin{array}{l}\text { As sequências descritiva (descrição da cidade, das atividades, excursões etc.) e injuntiva } \\
\text { (descrição de ações) são as predominantes. Podemos encontrar, também, um efeito argumentativo } \\
\text { da sequência descritiva, ao ressaltar os pontos fortes do local (não chega a ser a sequência } \\
\text { argumentativa, pois não tem o contra-argumento). Ou seja, neste tipo de texto, geralmente, só se } \\
\text { fala favoralmente ao local escolhido e ao pacote da agência, caso ele exista. }\end{array}$ \\
\hline
\end{tabular}




\begin{tabular}{|c|c|}
\hline \multicolumn{2}{|r|}{ COERÊNCIA TEMÁTICA } \\
\hline Conexão & $\begin{array}{l}\text { Não encontramos muitos elementos de conexão normalmente utilizados para a transição entre } \\
\text { os tipos de discurso e as fases de uma sequência. Os conectores mais frequentes são: «ensuite», } \\
\text { «après», «pendant»,, «puis» e servem para indicar as etapas de atividades e de excursões que serão } \\
\text { feitas pelos viajantes. As outras conexões são dadas por justaposição de conteúdos. }\end{array}$ \\
\hline Coesão nominal & $\begin{array}{l}\text { Alta densidade nominal. São utilizadas referências sobre a cidade para evitar a repetição do seu } \\
\text { nome ( "île de la Beauté”, "cette île”, "la capitale du royaume de la Belgique”, "la capitale de la } \\
B D \text { ” etc.); muitos adjetivos; léxico de viagem; nominalizações. As escolhas lexicais demonstram } \\
\text { um posicionamento do enunciador, que deseja convencer o leitor, por meio de adjetivos } \\
\text { qualificativos positivos e substantivos que têm a função de enaltecer o local. }\end{array}$ \\
\hline \multirow{3}{*}{ Coesão verbal } & $\begin{array}{l}\text { Bastante heterogeneidade. Destaque para o présent e o futur simple do indicativo, o impératif e } \\
\text { as nominalisations. }\end{array}$ \\
\hline & $\begin{array}{l}\text { A) Nominalisation e Futur simple presentes nas brochuras de agências. O futur é especialmente } \\
\text { importante para transmitir ao destinatário uma ideia de projeto }\end{array}$ \\
\hline & $\begin{array}{l}\text { B) e C) Os verbos aparecem geralmente no présent, utilizados para falar sobre as características da } \\
\text { região, como ela é. Há, também, o uso do impératif para indicar o que o turista deve fazer ou aonde } \\
\text { ele deve ir. Algumas frases são escritas no passado para contar algo histórico sobre a cidade ou país. }\end{array}$ \\
\hline \multicolumn{2}{|r|}{ COERÊNCIA PRAGMÁTICA } \\
\hline \multirow[t]{2}{*}{ Vozes } & $\begin{array}{l}\text { Encontramos a voz do autor. Os enunciados traduzem papéis diferentes assumidos pelo enunciador } \\
\text { de acordo com o local sobre o qual se escreve e de acordo com os destinatários almejados. Parece } \\
\text { que a declaração se adapta ao destinatário porque o enunciador quer produzir um efeito de } \\
\text { persuasão. Sendo assim, o enunciador pode assumir a voz de alguém que gosta de aventuras, de } \\
\text { alguém que gosta de história e assim por diante, buscando uma aproximação com o destinatário. }\end{array}$ \\
\hline & $\begin{array}{l}\text { A) Nos textos das agências, encontramos, também, a presença da voz do estrangeiro ("Sputinu", } \\
\text { "Braai", "Mezquita"), que aparece geralmente entre aspas e serve para dar ao leitor pequenos } \\
\text { elementos da cultura estrangeira. }\end{array}$ \\
\hline Modalizações & $\begin{array}{l}\text { Apreciativas. Encontramos muitos substantivos e adjetivos para exaltar a cidade (" grande } \\
\text { réputation », «lieu incontournable », « une vraie image de carte postale», " destination week- } \\
\text { end privilégiée ») e, também, a utilização de verbos amar e admirar («aimerez », «admirerez »). } \\
\text { A própria escolha lexical dos verbos e substantivos denota o intuito de enaltecer o local. }\end{array}$ \\
\hline
\end{tabular}

Fonte: A autora

\section{Considerações Finais}

O homem só tem acesso ao meio, através de uma atividade mediada pela língua, portanto, aprender uma língua estrangeira permite o acesso a um novo mundo social. A aprendizagem de uma língua estrangeira precisa levar o aluno a dominar as situações de comunicação, permitindo que ele aja no mundo, e, para isso, ele deve ser confrontado durante sua aprendizagem a situações reais (ou próximas da vida real). Os gêneros são uma forma de trazer as atividades sociais para a sala de aula. Dito de outra forma, a compreensão e a produção de gêneros textuais permitem que, durante sua aprendizagem, o aluno seja colocado diante de uma situação como se fosse real. 
Ao conversarmos ou escrevermos, estamos interagindo uns com os outros por meio da linguagem. Nessas interações, produzimos textos orais ou escritos que têm um formato e um estilo que lhes são característicos. A cada troca, buscamos um "modelo" já conhecido de como podemos organizar o nosso discurso e o empregamos, visando ao sucesso de nossa comunicação. Ou seja, para interagir, produzimos textos que seguem formas já existentes na sociedade, os gêneros textuais (BUENO, 2009).

Quando um gênero é utilizado para o ensinoaprendizagem de uma língua estrangeira, é importante conhecer em detalhes o gênero, a fim de respeitar a sua estrutura linguística e enunciativa. Isso é importante, pois, ainda que o texto não seja autêntico, ele precisa ser similar ao texto real. Caso contrário, não cumprirá o seu papel de permitir que o usuário da língua seja um ator social, uma vez que o aluno aprenderá um tipo de texto que não existe na prática. Para evitar que isso aconteça, é preciso conhecer a estrutura do gênero textual que será estudado, e isso é possível, através do modelo de análise de textos do interacionismo sociodiscursivo e da elaboração de um modelo didático, que fizemos nas seções anteriores.

Conhecer em profundidade um gênero textual contribui significativamente para que o professor ensine seus alunos a produzir textos desse gênero. Sem esse conhecimento, pode-se acabar trabalhando alguns conteúdos que não fazem parte de um determinado gênero textual. Em outras palavras, conhecer o gênero que está sendo trabalhado permite ao professor reconhecer em textos não autênticos elementos que não fazem parte daquele gênero e que afastam o aluno das situações reais ou próximas das reais. Não queremos com isso dizer que nenhum texto fabricado por livros didáticos conseguirá colocar os estudantes em situações próximas das reais. No entanto, textos que não forem elaborados respeitando as características gerais do gênero estudado poderão soar muito artificiais e, consequentemente, comprometer a aprendizagem.
Apesar de reforçamos a importância de se conhecer detalhadamente um gênero textual, antes de ensinar a produzi-lo, reconhecemos que as análises para entender as suas características e elaborar o seu modelo didático não são simples. Elas envolvem, em um primeiro momento, o levantamento de textos autênticos, o que por si só não é uma tarefa simples, especialmente, quando ensinamos uma língua estrangeira. Além disso, seria necessário dominar o modelo de análise de textos do ISD, a fim de depreender as características linguísticas e discursivas do gênero estudado. Finalmente, seria importante, também, realizar entrevistas com as pessoas que produzem esses textos, para poder compreender as características ligadas ao seu contexto de produção.

No nosso caso, demoramos bastante tempo para encontrar os textos autênticos do gênero itinéraire de voyage. Ao analisar os textos do gênero escolhido, percebemos que existe uma diversidade muito grande entre os textos dos diferentes suportes, o que representou um desafio para nós, no momento de elaborar o modelo didático desse gênero. Os textos das brochuras de agências eram muito diferentes dos textos de sites e de revistas de viagem. Nas primeiras, existe um objetivo comercial que é muito forte, pois aquele texto foi escrito para vender pacotes de viagens. Essa diferença de objetivo gera, também, diferenças em outros aspectos do texto, o que acaba representando um desafio para o pesquisador na hora de consolidar essas características no modelo didático do gênero.

Outro desafio que tivemos na elaboração do modelo didático foi que não encontramos nenhuma pesquisa sobre esse gênero ou sobre o agir social viajar. Assim, não tivemos acesso a conhecimentos científicos pré-existentes e, como não conseguimos conversar diretamente com os produtores do texto, nosso modelo didático foi resultado exclusivamente das análises dos textos autênticos, o que é uma limitação, quando consideramos as etapas determinadas por pesquisadores para a construção do modelo didático de um gênero textual. Contudo, 
apesar dessa limitação, consideramos que nossas análises desses textos representam contribuições às pesquisas sobre os gêneros textuais, particularmente, o itinéraire de voyage.

Essas dificuldades para elaborar o modelo didático nos levam a questionar se as análises deveriam ficar a cargo do professor. Conforme defende Schneuwly (2012), talvez fosse mais adequado ter equipes multidisciplinares, compostas por professores, pesquisadores, produtores dos textos autênticos, entre outros, cujo trabalho seria analisar os gêneros textuais e elaborar sequências didáticas em concordância com os textos encontrados nas práticas sociais e de acordo com o contexto particular de ensino. Esperar que o professor se encarregue, além de todas as suas funções, de analisar textos autênticos e de elaborar materiais didáticos, talvez seja um pouco irreal, dado todo o trabalho e dispêndio de tempo envolvidos.

A partir das análises que apresentamos neste artigo, esperamos auxiliar, sobretudo, professores de língua francesa que desejam trabalhar com gêneros textuais em sala de aula. Ao propor o modelo didático do gênero itinéraire de voyage, estamos primeiramente ampliando os estudos já existentes e possibilitando que professores e pesquisadores possam, a partir do modelo didático proposto, elaborar sequências didáticas sobre esse gênero. No caso do gênero itinéraire de voyage, seria possível trabalhar em sala de aula os verbos no imperativo e no futuro, as nominalizações e os conectivos temporais, relacionados às capacidades linguístico-discursivas, por exemplo. Além, é claro, de outros aspectos relacionados aos contextos de produção desses textos, ao conteúdo e à forma do gênero, os quais foram detalhados neste artigo.

\section{Referências}

BAKHTIN, Mikhail. Estética da criação verbal. São Paulo: Martins Fontes, 1997.
BRASIL. Ministério da Educação. Parâmetros curriculares nacionais de língua portuguesa: terceiro e quarto ciclos do ensino fundamental. Brasília: MEC/SEF, 1998.

BRONCKART, Jean-Paul. Atividade de linguagem, textos e discursos: por um interacionismo sociodiscursivo. São Paulo: Educ, 1999.

Pourquoi et comment analyser l'agir verbal et non verbal en situation de travail. In: BRONCKART, J.P.(Org.). Agir et discours en situations de travail. Genebra: Cahiers de la section des Sciences de 1'Education, 2004. p. 9-144,

- Atividade de linguagem, discurso e desenvolvimento humano. Campinas: Mercado de letras, 2006.

O agir nos discursos: das concepções teóricas às concepções dos trabalhadores. Campinas: Mercado de letras, 2008.

- Gêneros de textos, tipos de discurso e sequências: por uma renovação do ensino da produção escrita. São Paulo: Pontifícia Universidade Católica, 2010. Palestra.

BUENO, Luiza. Gêneros textuais: uma proposta de articulação entre leitura, escrita e análise linguística. In: CENP. Lingua portuguesa: ensinar a ensinar. São Paulo: Secretaria de Educação, 2009. p. 215-233.

CONSEIL DE L'EUROPE. Cadre europeen commun de référence pour les langues. Paris: Didier, 2001.

CRISTOVÃO, Vera Lucia Lopes. O gênero quarta capa no ensino de Inglês. In: DIONÍSIO, Angela Paiva; MACHADO, Anna Rachel; BEZERRA, Maria Auxiliadora. (Org.). Gêneros textuais e ensino. Rio de Janeiro: Lucerna, 2002. p. 105-116.

LOUSADA, Eliane Gouveia. Utiliser les genres textuels dans une perspective actionnelle. Revistas de Lenguas Modernas, Costa Rica, n. 8-9, 2008.

A abordagem do interacionismo sociodiscursivo para a análise de textos. In: ENCONTRO DE PÓS-GRADUANDOS EM ESTUDOS DISCURSIVOS DA USP, 2010, São Paulo. Anais... São Paulo: USP, 2010.

MACHADO, Anna Raquel; CRISTOVÃO, Vera Lucia Lopes. A construção de modelos didáticos de gêneros: aportes e questionamentos para o ensino 
de gêneros. Linguagem em (Dis)curso, Tubarão, v. 6, n. 3, p. 547-573, 2006.

MAINGUENEAU, Dominique. Análise de textos de comunicação. São Paulo: Cortez Editora, 2001.

MARCUSCHI, Luiz Antonio. Gêneros textuais: definição e funcionalidade. In: DIONÍSIO, Angela Paiva; MACHADO, Anna Rachel; BEZERRA, Maria Auxiliadora. (Org.). Gêneros textuais e ensino. Rio de Janeiro: Lucerna, 2002. p. 19-36.

SCHNEUWLY, Bernard; DOLZ, Joaquim. Gêneros orais e escritos na escola. Campinas: Mercado de Letras, 2004.

SCHNEUWLY, Bernard. Travail de l'enseignant et genres de texte: une approche instrumentale de l'enseignement de la langue première. In: COLÓQUiO LINGUAGEM E TRABALHO DOCENTE, 2012, São Paulo. Anais... São Paulo:

Faculdade de Educação, USP, 2012. 